\title{
Accuracy of Injectable Kb Acceptor Re-Visit during the Covid-19 Pandemic in PMB Yayuk Handayani Wagir District Malang Regency
}

\author{
Rosyidah Alfitri ${ }^{*}$, Astri Yunita ${ }^{2}$ \\ ${ }^{1}$ Prodi Sarjana Terapan Kebidanan, FIK, Institut Teknologi Sains dan Kesehatan RS dr. Soepraoen Jl. S. \\ Supriadi no. 22 Malang \\ ${ }^{2}$ Prodi DIII Kebidanan, STIKes Bhakti Mulia, Jl. Matahari No. 1 Tulungrejo Pare Kediri \\ * Corresponding author \\ E-mail:elfitri.mafaza@gmail.com
}

\begin{abstract}
The COVID-19 pandemic is a disease caused by coronavirus syndrome 2 (SARS-CoV2) that attacks the respiratory system acutely, and caused more than 106 million people to become infected with more than 2.3 million deaths worldwide. In the family planning and birth control services (KB) service there is a revisit of kb active acceptor (old acceptors) and or visits of new acceptor is an effort to get contraceptive services aimed to prevent pregnancy. The purpose of our study was to see the difference in the accuracy of KB acceptor visits before and after the COVID-19 pandemic in Midwifery clinic (PMB) Yayuk Handayani Wagir District of Malang Regency. This research was quantitative research using experimental quasi research design with a pre post design approach. The sample in the study was the same as the study population of 50 injectable birth control acceptors in BPM Yayuk Handayani Wagir Magelang Regency. Research techniques use total sampling. In this data analysis, the normality test was carried out first, then the bivariate test used the dependent sample t-test. The results of the analysis test showed that before the COVID-19 pandemic, there were 43 revisits for active acceptors who matched the return date, while during the COVID-19 pandemic, 7 people were late for return visits and 11 people did not return for revisits. Obtained a value of $p$ value of 0.000 which is less than 0.05 so it can be concluded there is a difference in the accuracy of visits before and during the COVID-19 pandemic. It can be concluded that there is a difference in the return visit of hormonal contraceptive acceptors in PMB Yayuk Handayani Wagir District of Malang Regency.
\end{abstract}

Keywords: contraceptive acceptors, hormonal contraceptive, Covid-19

\section{INTRODUCTION}

One of the problems in a country is the high birth rate. The high number of population increases that are not balanced with production capabilities will lead to high development burdens related to boards, clothing and food. Population density is not balanced with the existence of employment so that the increasing number of unemployed and low economic levels of a nation. This is a big problem for BKKBN. ${ }^{[1]}$ The National Population and Family Planning Agency (BKKBN) as a department that serves to control the population and 
maintain family planning so that the establishment of a prosperous family in Indonesia. A prosperous family is a family formed by a legitimate marriage, able to meet the needs of a proper spiritual and material, fear God Almighty, have a harmonious, harmonious, and balanced relationship between members and between families and the community and its environment. ${ }^{[2]}$

The COVID-19 pandemic is a disease caused by coronavirus syndrome 2 (SARS-CoV-2) that attacks the respiratory system acutely, which has caused more than 106 million people to become infected and more than 2.3 million deaths worldwide. ${ }^{[3]}$ By February 2021, according to WHO the COVID-19 virus can be reduced in spread by measures implemented by all countries that of course affect life globally. This pandemic greatly affected mental health for society, resulting in loneliness, social isolation, economic stress, anxiety and fear of contracting the virus and uncertainty for the future. ${ }^{[4]}$

From restriction and quarantine to extraordinary situations to prevent the spread of pathogens that cause acute and serious infectious diseases, namely COVID19. One possible consequence of these types of changes may be related to the area of use of contraceptive methods during quarantine or restriction periods. In Spain, a population of about $18.5 \%$ of the childbearing age uses combination oral contraceptives to prevent pregnancy. This contraceptive should be prescribed by a doctor. According to Lete et al in his article on dovepress August 2021, it is hypothesized that the period of restriction or quarantine negatively affects accessibility on KB acceptors. ${ }^{[5]}$

In the contraception service there is a revisit of $\mathrm{KB}$ participants (old acceptors) and or visits of new participants (new acceptors), is an effort to get contraceptive services aimed at preventing pregnancy. The use of contraceptives is not only for Couples of Childbearing Age (PUS) who plan to pursue birth, but also for PUS that will delay pregnancy and or even end pregnancy or fertility. ${ }^{[6]}$ Birth control acceptor visits to health services that require getting out of the house and meeting with health workers to get services, while the spread of the virus outside is very fast and not easy to detect. This causes birth control acceptors to delay not even returning to health facilities. The survey results of mostly 20-35 year olds are $145(78.4 \%), 135(72.4 \%)$ respondents use contraceptives, the reason respondents who do not use contraceptives are 20 (40\%), Most of $117(87 \%)$ respondents of old birth control acceptors and $56(41 \%)$ use injectable contraceptives 3 months, make repeated visits according to the stipulated time of $90(67 \%)$, as many as $20(18.18 \%)$ have been late injectable / forgot the pill among them $9(45 \%)^{[7]}$.

Therefore, the purpose of this research is to see the difference in the accuracy of kb acceptor visits before and after the COVID-19 pandemic in PMB Yayuk Handayani Wagir District of Malang Regency.

\section{METHOD}

This research includes a type of quantitative research using experimental quasi research design with a pre post design approach. This study compared the accuracy of repeated visits of injectable birth control acceptors before and after the Covid-19 pandemic. The population in this study is all injectable birth control acceptors in PMB Yayuk Handayani Wagir Magelang Regency. The research technique uses total sampling, where all 50 injectable birth control acceptors in BPM Yayuk Handayani Wagir Magelang Regency was becoming the sample.

The independent variable was Covid-19 Pandemic and the dependent variable was accuracy of $\mathrm{KB}$ acceptor revisit. Data collection instruments for research use a checklist filled out by researchers. Analytics are done with univariate and bivariate analysis. In bivariate analysis performed normality test and bivariate test using statistics dependent samples t-test. In the calculation process is 
assisted by using the help of Statistic Program for Social Science (SPSS) Version 23.

\section{RESULT}

The results of this study are presented in several tables, including the characteristic tables of respondents, namely table 1 age, table 2 education and table 3 jobs. While special data is presented in pre and post pandemic tables and cross tables. Here are the results presented in the table

Table 1.Frequency distribution of KB acceptors based on age

\begin{tabular}{lcc}
\hline Age & Frequency(n) & $\begin{array}{c}\text { Percentage } \\
(\%)\end{array}$ \\
\hline $20-35$ y.o & 29 & 58 \\
$36-45$ y.o & 16 & 32 \\
$>46$ y.o & 5 & 10 \\
Total & 50 & 100 \\
\hline
\end{tabular}

Based on table 1 above, most hormonal birth control acceptors (injectables) aged 20-35 years, which amounted to 29 people (58\%), while a small percentage of 5 people (10\%) with the age of more than 46 years.

Table 2. Distribution of Frequency of KB acceptors based on education

\begin{tabular}{lcc}
\hline Education & $\begin{array}{c}\text { Frequency } \\
(\mathrm{n})\end{array}$ & $\begin{array}{c}\text { Percentage } \\
(\%)\end{array}$ \\
\hline SD & 5 & 10 \\
SMP & 28 & 56 \\
SMA & 17 & 34 \\
Total & 50 & 100 \\
\hline
\end{tabular}

Based on table 2 above, most of the last educated hormonal birth control acceptors (injectables) of junior high school are 28 people $(56 \%)$, while a small percentage of elementary school education amounted to 5 people (10\%).

Table 3. Frequency distribution of KB acceptors based on work

\begin{tabular}{lcc}
\hline Category & $\begin{array}{c}\text { Frecuency } \\
(\mathrm{n})\end{array}$ & $\begin{array}{c}\text { Percentage } \\
(\%)\end{array}$ \\
\hline IRT & 9 & 18 \\
Swasta & 36 & 72 \\
\hline
\end{tabular}

\begin{tabular}{lcc}
\hline Wiraswasta & 5 & 10 \\
Total & 50 & 100 \\
\hline
\end{tabular}

Based on table 3 above, most of the hormonal $\mathrm{kb}$ (injectable) acceptors work privately, namely 36 people $(72 \%)$, the majority of the residents of wagir subdistrict are working as employees of cigarette factories that stand in the region.

While the data on the accuracy of hormonal $\mathrm{KB}$ acceptor visits in PMB Yayuk Handayani Wagir District of Malang Regency is presented in the pre and post graph of visit accuracy. Here's the graph:

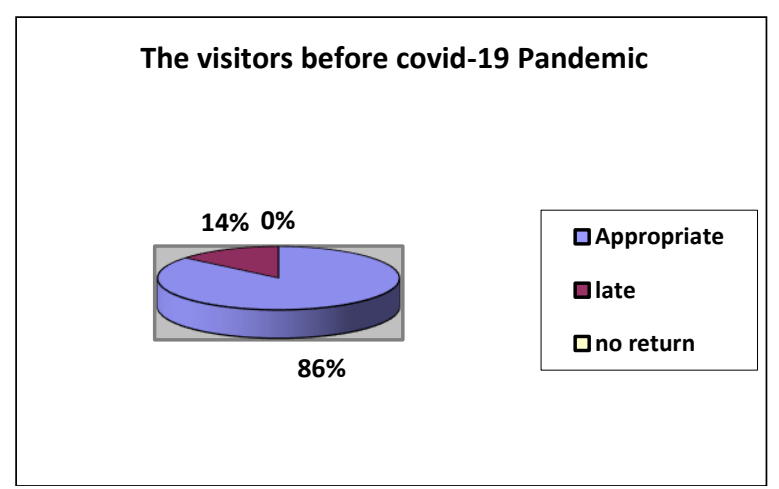

Chart 1 Revisit of Injecting KB Acceptors Before the COVID-19 Pandemic at BPM Yayuk Handayani Wagir Malang Regency

Based on the graph above the accuracy of visits before the COVID-19 pandemic at PMB Yayuk Handayani mostly make repeat visits according to the return date of 43 people.

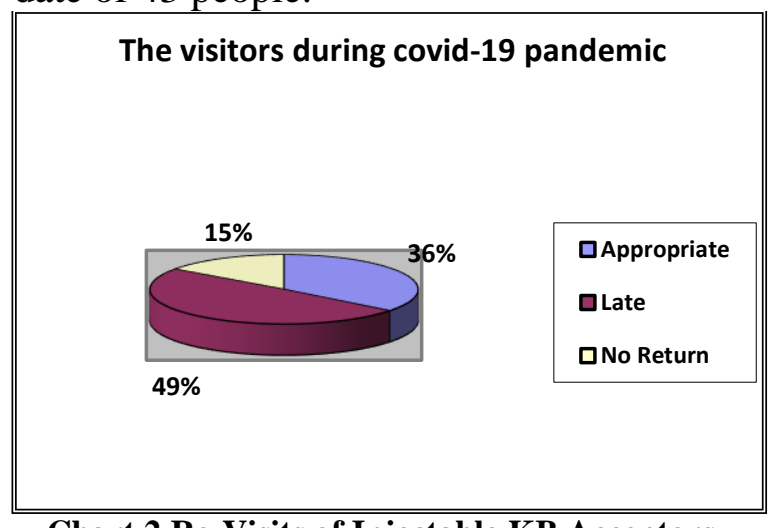

Chart 2 Re-Visits of Injectable KB Acceptors Before the COVID-19 Pandemic in BPM Yayuk Handayani Wagir Malang Regency

Based on chart 2 above, the accuracy of visits during the COVID-19 pandemic at PMB Yayuk Handayani who made a repeat visit according to the return date were 26 
people. Those who did not return were 11 people.

Table 4. Cross Table of the accuracy of visits of hormonal KB acceptors before the pandemic and during the pandemic in PMB

Yayuk Handayani Wagir District of Malang Regency

\begin{tabular}{|c|c|c|c|c|}
\hline \multirow{2}{*}{$\begin{array}{l}\text { Sebelum } \\
\text { pandemi }\end{array}$} & \multicolumn{4}{|c|}{ Selama Pandemi COVID-19 } \\
\hline & Tepat & Telat & $\begin{array}{l}\text { Tidak } \\
\text { Kembali }\end{array}$ & Total \\
\hline Tepat & 26 & 6 & 11 & 43 \\
\hline Telat & 0 & 7 & 0 & 7 \\
\hline total & 26 & 13 & 11 & 50 \\
\hline
\end{tabular}

Based on the cross table above obtained before the pandemic that did a repeat visit exactly obtained 43 people, out of 43 people during the pandemic that came exactly 26 people, late visits 6 people and who did not return a number of 11 people. Which before the pandemic came late a number of 7 people during the pandemic remained 7 people.

The results of the data normality test with the Kolmogorov Smirnov test showed a figure of 0.000 , this means the data is not normal. So bivariate analysis uses dependent samples t-test. Obtained a value of $p$ value of 0.000 which is less than 0.05 so it can be concluded there is a difference in the accuracy of visits before and during the COVID-19 pandemic.

\section{DISCUSSION}

Based on the results of research on the accuracy of visits before the COVID-19 pandemic at PMB Yayuk Handayani mostly made repeat visits according to the return date of 43 people.

Globally, there are about $50 \%$ of unwanted pregnancies. In low- and middleincome countries where access to health care is limited, things that will be a problem include abortion, pregnancy with complications, this will lead to the death of mother and baby. ${ }^{[8]}$ Contraception will save from problems that occur so that it becomes an important component in reproductive health services. A woman's ability to access health services and use contraception regularly will increase a woman's reproductive autonomy and will reduce unwanted pregnancies. Unwanted pregnancies greatly impact women and families, life, health, empowerment, wellbeing especially during stressful and difficult conditions. ${ }^{[9]}$ Therefore regular and timely visits of birth control acceptors are an attempt to prevent unwanted pregnancies.

Based on chart 2 above the accuracy of visits during the COVID-19 pandemic at PMB Yayuk Handayani made a revisit 26 people and did not revisit 11 people.

During the COVID-19 pandemic there are restrictions in any sector including in the health care provider must adjust the way contraceptive services are provided with telehealth methods for counseling, joint decision making, management of acceptor complaints and must make adjustments to the provision of contraceptive services ${ }^{[10]}$

The re-visit of contraceptive acceptors during the Covid-19 pandemic continues, but some anxiety occurs during the visit. Visits to contraceptive providers are determined by several things, including access to health workers or family planning service providers (PLKB), the availability of contraceptives embraced by WHO acceptors. Declared coronavirus (COVID19) a global health emergency or pandemic. The Indonesian government has designated the non-natural disaster spreading COVID19 as a National Disaster. In the face of the COVID-19 non-natural disaster outbreak, a large-scale social restriction policy (PSBB) was carried out for the prevention of COVID-19 transmission. This condition causes impacts on the continuity of public health services, including contraceptive services and reproductive health. Government policies to implement social distancing, physical distancing, work from home as an effort to prevent the transmission of covid-19, causing difficult access of KB acceptors to KB services. ${ }^{[11]}$

In pandemic conditions it is expected that couples of childbearing age especially in couples with 4 Too (4T) are expected to 
delay their pregnancy first and health workers continue to monitor them in contraceptive use. During the covid 19 pandemic, obstetrics services, especially women's reproductive health services, are still carried out of course by applying the principles of prevention of infection control and physical distancing. The family planning service guide states that the message that must be conveyed to the community is (1) Delay pregnancy until the pandemic conditions end, (2) Birth control acceptors should not come to health workers, except those who have complaints, provided that they make an agreement in advance with health workers, (3) For IUD or implant acceptors who have expired, if it is not possible to come to health workers can use condoms that can be obtained in Engan contacted the family planning service provider (PLKB) or cadre by phone. If it is not available can use traditional means (periodic abstinence or severed intercourse), (4) For injectable acceptors are expected to come to health workers according to schedule by making previous agreements. If this is not possible, you can use condoms that can be obtained by contacting a family planning service provider (PLKB) or cadre by phone. If it is not available to use traditional means (periodic abstinence or disconnection), (5) For Pill acceptors are expected to contact family planning service providers (PLKB) or cadres or Health Workers via phone to get hormonal pills, (6) Mothers who have given birth should directly use postnatal contraception (KBPP), (7) Communication, Information, and Education Materials (KIE) and the implementation of birth control-related counseling can be obtained online or telephone consultation ${ }^{[12]}$.

Access to health care facilities was very limited and people began to avoid health facilities due to concerns of contracting COVID-19. One in three women (33\%) reported that due to a pandemic, had to postpone or cancel a visit to a health care provider ${ }^{[13][14]}$.

\section{CONCLUSION}

From the results of this study it was found that the accuracy of re-visits on hormonal contraceptive acceptors most of the re-visits corresponded to the return date or were said to be 'appropriate', while during the pandemic the accuracy of the acceptable acceptor's return visit 11 people did not make a re-visit or did not return. It can be concluded that there is a difference in the return visit of hormonal contraceptive acceptors in PMB Yayuk Handayani Wagir District of Malang Regency.

\section{ACKNOWLEDGMENTS}

The author thanked (1) the Institute of Science and Health Technology of Dr. Soepraoen Malang Hospital, and (2) STIKes Bhakti Mulia Kediri, who have provided material support so that research and this article can be realized properly.

\begin{tabular}{l}
\hline REFERENCE \\
\hline 1. Kementerian Kesehatan Republik \\
Indonesia (2017) Survey Demografi dan \\
Kesehatan Indonesia, Survei Demografi \\
dan Kesehatan Indonesia 2017.
\end{tabular}

2. Undang-undang Nomor 10 Tahun 1992 tentang Perkembangan Kependudukan dan Pembangunan Keluarga Sejahtera.

3. RDA COVID-19 Working Group (2020) 'Recommendations and Guidelines on data sharing', Research Data Alliance, p. 124. doi: https://doi.org/10.15497/rda00052.

4. Phelan N, Behan LA, Owens L (2021). The Impact of the COVID-19 Pandemic on Womens Reproductive Health. Frontiers in Endocrinology. March 2021. Volume 12. Article 642755.

5. Lete I, Novalbos J, Viuda ED, Lugo F, Herrero M, Obiol M, Perello J, Borrego RS (2021) Impact of The Lockdown Due to COVID-19 Pandemic in the Use of Combined Hormonal Oral Contraception in Spain- Result of 
National Survey: Encovid. DovePress. Open Access Journal of Contraception 2021:12 103-111

6. Mawarni, A. (2016) 'Hubungan Persepsi Akses Dan Pelayanan

7. KB dengan Kejadian Unmet', Jurnal Penelitian Kesehatan Suara Forikes, 7(1), pp. 32-38.

8. Sirait LI (2021) Kunjungan Akseptor KB di Masa Pandemi COVID-19. Prosiding Seminar Nasional STIKES Syedza Saintika. Pp. 235-245

9. Nanda K, Lebetkin E, Steiner MJ, Yacobson I, Darflinger LJ. (2020). Contraception in the COVID-19. Global Health: Science and Practice 2020 | Volume 8 | Number 2

10. Purwanti, S. (2020) 'Dampak Penurunan Jumlah Kunjungan Kb Terhadap Ancaman Baby Boom Di Era Covid-19', Jurnal Bina Cipta Husada, XVI(2), pp. 105-118.

11. Grasilia Febriani, E. (2018) 'Faktorfaktor yang berhubungan dengan penggunaan alat kontrasepsi pada wanita usia subur (WUS)', Jurnal Mahasiswa Kesehatan Masyarakat, 1(1), pp. 37-44.

12. 'Pedoman Standar Perlindungan Dokter di Era Covid-19', Ikatan Dokter Indonesia, p. 40.

13. Kemenkes RI (2020) 'Panduan Pelayanan Keluarga Berencana dan Kesehatan Reproduksi Dalam Situasi Pandemi COVID-19', kemenkes RI, p. 5

14. Benson, L. S. et al. (2020) 'Society of Family Planning interim clinical recommendations: $\quad$ Contraceptive provision when healthcare access is restricted due to pandemic response', Society of Family Planning, pp. 1-9.
15. Lindberg, L. et al. (2020) 'Early Impacts of the COVID-19 Pandemic: Findings from the 2020 Guttmacher Survey of Reproductive Health Experiences', (June), pp. 1-14. Available at: www.guttmacher.org. 